\title{
Cold-inducible RNA binding protein (CIRP) expression is modulated by alternative mRNAs
}

\author{
MOHAMED B. AL-FAGEEH and C. MARK SMALES \\ Protein Science Group, Department of Biosciences, University of Kent, Canterbury, Kent, CT2 7NJ, United Kingdom
}

\begin{abstract}
Cold-inducible RNA binding protein (CIRP) is a mammalian protein whose expression is up-regulated in response to mild hypothermia. Although the exact function of this protein is currently unknown, it is thought to function as an RNA chaperone, facilitating mRNA translation upon the perception of cold stress. In this study we have identified and characterized the major CIRP 5' -untranslated region (5'-UTR) transcripts in mouse embryonic fibroblast NIH-3T3 cells. We show that the 5'-UTR of CIRP, a protein highly homologous to the cold-shock protein $\mathbf{R b m} 3$, is much shorter than the previously published $5^{\prime}$ leader sequence of $R b m 3$. In addition, three major $C I R P$ transcripts with different transcription start sites are generated, with the levels of each of these transcripts being regulated in response to time and temperature. The major transcript generated at $37^{\circ} \mathrm{C}$ does not encode for the full-length CIRP open reading frame, while the two major transcripts at $32^{\circ} \mathrm{C}$ do. Further, the longest transcript detected at $32^{\circ} \mathrm{C}$ shows a discrete expression and stability profile under mild hypothermic conditions and exhibits internal ribosome entry segment (IRES)-like activity. The IRES-like activity is not responsive to conditions of mild hypothermia or hypoxia, but the levels and stability of the transcript harboring the putative IRES are increased at $32^{\circ} \mathrm{C}$. We discuss the emerging transcriptional and translational mechanisms by which CIRP expression appears to be controlled and the role that the 5 '-UTR plays in the modulation of CIRP expression.
\end{abstract}

Keywords: cold-inducible RNA binding protein; cold shock; 5'-UTR; mRNA stability; alternative transcription start sites; IRES

\section{INTRODUCTION}

Temperature change is possibly the most common form of environmental stress that all organisms are regularly subjected to. While the cellular responses of both prokaryotic and eukaryotic systems to heat stress have been widely investigated, the responses to cold stress are comparatively poorly defined (Al-Fageeh and Smales 2006; Al-Fageeh et al. 2006). The general response to cold stress involves the suppression of transcription, translation, and metabolic processes; however, there is a subset of proteins whose synthesis is either maintained or up-regulated upon cold shock (Ermolenko and Makhatadze 2002). By far, the most well characterized system is the response in Escherichia coli, whereby around 27 of these so termed cold-shock proteins have been identified to date (Gualerzi et al. 2003). Although the exact role of most of these proteins upon cold stress is yet to be fully elucidated, the majority are thought to be

Reprint requests to: C. Mark Smales, Protein Science Group, Department of Biosciences, University of Kent, Canterbury, Kent, CT2 7NJ, United Kingdom; e-mail: c.m.smales@kent.ac.uk; fax: +44 01227763912.

Article published online ahead of print. Article and publication date are at http://www.rnajournal.org/cgi/doi/10.1261/rna.1179109. involved in the modulation of a variety of fundamental cellular functions that govern cell fate including transcription and translation, but also DNA replication, RNA stabilization, and ribosome assembly (Gualerzi et al. 2003).

Mammalian cells are also known to respond to mild cold stress (typically $32^{\circ} \mathrm{C}$ ) via the induction of a number of cold-shock proteins (Al-Fageeh and Smales 2006; Roobol et al. 2009). Only two cold-shock proteins have been extensively characterized in mammalian systems to date: cold-inducible RNA binding protein (CIRP) and RNA binding motif protein 3 (Rbm3) (Derry et al. 1995; Danno et al. 1997). CIRP and Rbm3 belong to a highly conserved glycine-rich RNA-binding protein family, and although the exact function(s) of these cold-inducible proteins is unknown, it is thought that they modulate translation (Dresios et al. 2005; Smart et al. 2007) and function as RNA chaperones that facilitate translation upon the perception of cold stress (Fujita 1999). Recent reports suggest that $\mathrm{Rbm} 3$ is also involved in the global regulation of protein synthesis at both physiological $\left(37^{\circ} \mathrm{C}\right)$ and mildhypothermic temperatures $\left(32^{\circ} \mathrm{C}\right)$ via the alteration of microRNA-containing complexes (Dresios et al. 2005), while CIRP appears to play a key role in activation of the 
extracellular signal-regulated kinase pathway, thereby protecting cells from tumor necrosis factor TNF- $\alpha$ induced apoptosis (Sakurai et al. 2006).

The $5^{\prime}$-untranslated region (UTR) of the mRNA encoding Rbm3 has been investigated by Mauro and co-workers at length, resulting in the identification of a number of regulatory elements that respond to mild hypothermia within this region (Chappell et al. 2001; Chappell and Mauro 2003). Analysis of the lengthy 720 -nucleotide (nt) $5^{\prime}$ cDNA leader sequence revealed 13 upstream open reading frames, and further investigation showed that the $5^{\prime}$-UTR of $R b m 3$ mediated enhanced cap-independent mRNA translation at $33^{\circ} \mathrm{C}$ compared with that observed at $37^{\circ} \mathrm{C}$, suggesting the presence of an internal ribosome entry segment (IRES) (Chappell et al. 2001). Deletion and mutation analysis on the putative IRES revealed the presence of at least nine discrete cis-acting sequences including a 22-nt IRES module, a 10-nt enhancer, and two inhibitory sequences (Chappell and Mauro 2003). The authors also demonstrated that four cis-acting sequences within the 5 '-UTR most likely bind specifically to different cytoplasmic proteins (Chappell and Mauro 2003). Thus, the 5'-UTR of Rbm3 mRNA initially appeared to contain a number of regulatory elements that mediate cap-independent mRNA translation under mild-hypothermic conditions, despite the attenuation of general (cap-dependent) mRNA translation. However, recent studies have reported that the putative IRES activity of the Rbm3 transcript appears to be the result of a cloning artifact (Baranick et al. 2008).

Despite the extensive investigations into the $5^{\prime}$-UTR of $R b m 3$ mRNA, there has been no investigations into whether the $5^{\prime}$ leader sequence of CIRP contains any elements that are involved in control of its expression upon cold stress, or indeed if alternative mRNAs are produced upon cold stress. This prompted us to identify and characterize the $5^{\prime}$-UTR of the transcript encoding CIRP at varying temperatures and times in order to elucidate the mechanisms that control the expression of CIRP at the mRNA level at normal and reduced temperatures. Here we show that the $5^{\prime}$-UTR of CIRP mRNA is much shorter than that of the reported Rbm3 mRNA that was initially thought to contain an IRES element. Further, a significantly longer CIRP $5^{\prime}$-UTR is detected upon cold stress for $6 \mathrm{~h}$ at $32^{\circ} \mathrm{C}$ relative to that observed $24 \mathrm{~h}$ post-cold stress. The longer $5^{\prime}$-UTR transcript detected at $32^{\circ} \mathrm{C}$ shows discrete expression and stability profiles under mild hypothermic conditions with differences in turnover and stability relative to that observed at $37^{\circ} \mathrm{C}$. The longer transcript exhibits internal ribosome entry segment (IRES) activity and no evidence of splicing to generate monocistronic transcripts was detected that might account for the observed IRES activity. We also show that the entire $5^{\prime}$-UTR of the longer CIRP mRNA is required to maintain IRES activity and that CIRP expression upon mild-hypothermic temperature stress and the longer-term adaptive cellular response is, at least in part, controlled at the mRNA level.

\section{RESULTS}

The CIRP 5' -UTR mRNA leader sequence is regulated by alternative transcription start sites in response to time and temperature

A 5'RNA ligase-mediated rapid amplification of cDNA ends (RLM-RACE) approach was used to identify the transcription start site in CIRP cDNA from NIH-3T3 cells upon mild hypothermic cold shock at $32^{\circ} \mathrm{C}$ for 6 or $24 \mathrm{~h}$, respectively. In control cells cultured at $37^{\circ} \mathrm{C}$ the CIRP $5^{\prime}$-UTR was short, indeed the major transcription start site was located immediately after the cDNA open reading frame ATG start codon (here after referred to as the control-UTR) (Fig. 1B,C). However, under mild hypothermic conditions extended 5'-UTRs were detected (Fig. 1A,B). The first alternative transcription start site, detected after mild hypothermic cold shock at $32^{\circ} \mathrm{C}$ for $24 \mathrm{~h}$, generated a $5^{\prime}$-UTR consisting of $82 \mathrm{nt}$ upstream of the open reading
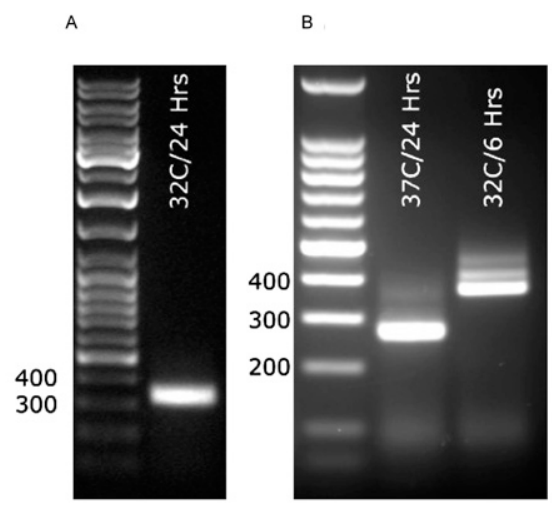

c

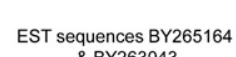
\& BY263043

AGATGCCGAATCTAAGGCGTCGGATTGGTCAGCGCGGCGTGGTGGGCGGGTT

AAGGGGCGTGGCTCCAGGAGTGGAGTATATCAGGCGGGACTCTTGCGCTCCC

CCTCCCACTCGCGCCTTAGGAAGCTTGGGTGTGTGTGGCGCGCTGTCTTCCCG

CTCGCGTCAGGGACCTGCCCGACTCAGCG...(1891 bp)...GCTGCCAAGGCATCA

GATGAAGGCAAGCTTTTCGTGGGAGGACTCAGCTTCGACACCAACGAGCAGGC

FIGURE 1. Identification of transcription start sites of CIRP cDNA using a $5^{\prime}$ RNA ligase-mediated rapid amplification of cDNA ends method (RLM-RACE). Total RNA was isolated from NIH-3T3 cells cold shocked at $32^{\circ} \mathrm{C}$ for $(A) 24 \mathrm{~h}$ and $(B) 6 \mathrm{~h}$ and subjected to RLMRACE analysis. Control cells were cultured at $37^{\circ} \mathrm{C}$ for $24 \mathrm{~h}$ before RLM-RACE analysis $(B)$. The appropriate primers are detailed in Table 1. $(C)$ The sequence of the resulting transcripts, the transcription start sites (as indicated by arrows), the ATG translation start site (underlined), and two EST sequences in public databases are indicated on the cDNA aligned to the genomic DNA sequence. The location of the $5^{\prime}$-UTR intron is also depicted (1891 bp). For further details see the text. 
frame ATG start codon (here after referred to as the short $5^{\prime}$ UTR) (Fig. 1A,C). This transcription start site is the same as that previously published when mouse CIRP was originally cloned (Nishiyama et al. 1997b). On the other hand, when cells were subjected to cold shock at $32^{\circ} \mathrm{C}$ for only $6 \mathrm{~h}$ an alternative transcription start site was detected (Fig. 1B). This transcription start site generated an extended $5^{\prime}$ leader sequence of an additional $43 \mathrm{nt}$ compared with that observed after $24 \mathrm{~h}$ at $32^{\circ} \mathrm{C}$, resulting in a $5^{\prime}$-UTR consisting of $125 \mathrm{nt}$ upstream of the cDNA open reading frame ATG start codon (hereafter referred to as the long $5^{\prime}$-UTR) (Fig. 1C). Alignment of the full-length CIRP cDNA, including the characterized $5^{\prime}$-UTRs, with mouse chromosome 10 using the NCBI Spidey software showed that generation of the two longer $5^{\prime}$-UTRs observed under conditions of mild hypothermia at $32^{\circ} \mathrm{C}$ required the splicing out of $1891 \mathrm{nt}$ from the primary transcript (Fig. 1C). The two leader sequences detected at $32^{\circ} \mathrm{C}$ contain the $6 \mathrm{nt}$ immediately upstream of the ATG open reading frame start codon, at which point the 1891 base-pair (bp) segment immediately upstream is spliced out (see Fig. 1C). The extended 43 nt found in the long $5^{\prime}$-UTR are those immediately upstream of the short $5^{\prime}$-UTR transcription start site in the genomic sequence, and is therefore generated entirely as a result of an alternative transcription start site and does not involve additional splicing events.

As CIRP is closely related to the cold-shock protein Rbm3, we compared the CIRP 5'-UTRs with the published $R b m 35^{\prime}$-UTR. Despite the presence of an extended 5'-UTR at reduced temperature, the identified CIRP leader sequence is much shorter than the 720-nt leader sequence in the Rbm3 transcript (Chappell et al. 2001; Chappell and Mauro 2003). Further, there were no sequence similarities between the CIRP 5'-UTR identified in this study and the previously published Rbm3 5'-UTR, which has now been reported to contain cloning artifacts (Baranick et al. 2008).

\section{Endogenous levels of the CIRP transcripts are regulated in response to time and temperature}

The presence of the long CIRP 5'-UTR was initially confirmed in total RNA isolates from NIH-3T3 cells subjected to mild hypothermia at $32^{\circ} \mathrm{C}$ for $2,6,12$, and $24 \mathrm{~h}$, and control cells left at $37^{\circ} \mathrm{C}$, using nested polymerase chain reaction (PCR) and primers specific for the long UTR (Fig. $2 A)$. Primers to the short UTR were also designed that would amplify both the long and short UTRs to show the combined levels of these transcripts. CIRP gene specific primers were also used to confirm the presence of the CIRP open reading frame transcript, while $\beta$-actin primers were used as a control (Fig. 2A). This approach confirmed the presence of the long $5^{\prime}$-UTR in all samples, including the control sample at $37^{\circ} \mathrm{C}$ (Fig. $2 \mathrm{~A}$ ), although this approach gives no information on the level of this transcript under the different conditions. Thus, the long and combined



FIGURE 2. (A) Quantitative real-time PCR ( $q$ RT-PCR) analysis of the levels of the long and short CIRP transcripts: Total RNA was isolated from NIH-3T3 cells cold shocked at $32^{\circ} \mathrm{C}$ for $2,6,12$, and $24 \mathrm{~h}$, or left to grow at $37^{\circ} \mathrm{C}$ for $24 \mathrm{~h}$. The presence of the long ( $\left.5^{\prime}-\mathrm{UTR}-\mathrm{L}\right)$ and short (5'-UTR-S) $5^{\prime}$-UTRs, and the CIRP opening reading frame (ORF) transcript, was confirmed by nested PCR using specific primers. The presence of $\beta$-actin was detected as a control. The specific primers utilized are described in Table 1. Subsequently, total RNA was subjected to $q$ RT-PCR using specific primers for the (B) CIRP ORF, $(C)$ short 5'-UTR, and $(D)$ long $5^{\prime}$-UTR and the relative levels of each message compared with the $37^{\circ} \mathrm{C}$ control determined. All data shown are the means of triplicate experiments \pm SD.

$5^{\prime}$-UTR transcripts were detected even at $37^{\circ} \mathrm{C}$ using this approach, however these were not conclusively detected using the 5' RACE approach, although several faint bands that might correspond to the short and longer $5^{\prime}$-UTRs are present upon RACE analysis (see Fig. 1B).

The relative levels (compared with control $37^{\circ} \mathrm{C}$ samples) of (1) the CIRP open reading frame transcript, (2) the long 5 '-UTR, and (3) the combined $5^{\prime}$-UTR transcripts were determined using quantitative real-time PCR ( $q$ RT-PCR). The levels of each were normalized relative to $\beta$-actin mRNA levels as previous reports have shown that $\beta$-actin mRNA levels remain constant in mammalian cells cultured at temperatures between 30 and $37^{\circ} \mathrm{C}$ (Fox et al. 2005; Marchant et al. 2008). The levels of the CIRP open reading frame transcript initially increased in response to mild hypothermia, reaching a maximum level $6 \mathrm{~h}$ post-temperature downshift (Fig. 2B). At this time an approximate fourfold increase in the level of the open reading frame transcript relative to the $37^{\circ} \mathrm{C}$ control level was observed (Fig. 2B). However, $12 \mathrm{~h}$ post-cold shock the levels of the open reading frame transcript had decreased and were approximately half the maximum level observed after $6 \mathrm{~h}$ (Fig. 2B). Despite this drop, the level of the open reading frame transcript $12 \mathrm{~h}$ post-cold shock was still approximately twice that detected in the $37^{\circ} \mathrm{C}$ control, and this 
level was maintained until at least $24 \mathrm{~h}$ after temperature downshift (Fig. 2B).

Western blot analysis confirmed that CIRP protein expression was also induced upon temperature downshift to accompany the increase in mRNA levels (Fig. 3), as previously reported by others (Nishiyama et al. 1997a,b; Fujita 1999). Analysis of the immunoblot protein data reveals that upon cold-stress CIRP protein levels are significantly increased $6 \mathrm{~h}$ post-cold shock in agreement with the open reading frame mRNA levels that are also increased at this time (Fig. 3B vs. Fig. 2B). Further, at $24 \mathrm{~h}$ post-cold stress, the levels of CIRP protein are approximately twice that of control samples maintained at $37^{\circ} \mathrm{C}$ (Fig. 3B). Interestingly, $12 \mathrm{~h}$ post-cold shock there was a consistent reduction in the CIRP protein levels detected relative to those observed after $6 \mathrm{~h}$ before the levels once again increased at $24 \mathrm{~h}$ (Fig. 3B). This drop at $12 \mathrm{~h}$ in protein levels mirrors the open reading frame mRNA profile (Fig. 2B), while the increase in protein levels at 24 $\mathrm{h}$ post-cold stress is not reflected by a further increase in the open reading frame mRNA levels, but does follow an increase in the long transcript mRNA levels (Fig. 2D).

The level of the total combined CIRP 5'-UTRs leader sequences mirrored the expression profile of the open reading frame as might be expected, with levels peaking 6 $\mathrm{h}$ post-cold shock and being reduced $12 \mathrm{~h}$ post-cold shock compared with those at $6 \mathrm{~h}$ post-cold shock (Fig. 2C). On the other hand, the long 5'-UTR exhibited a unique expression profile over the $24 \mathrm{~h}$ period following temperature downshift to $32^{\circ} \mathrm{C}$ (Fig. 2, cf. D and B,C). Within $6 \mathrm{~h}$ of temperature downshift, when the levels of the open reading frame transcript and combined $5^{\prime}$-UTRs peaked, the levels of the long $5^{\prime}$-UTR were also elevated, albeit
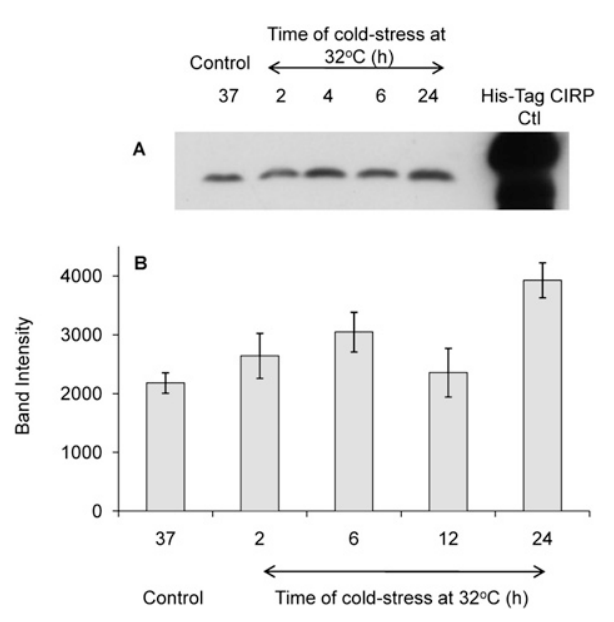

FIGURE 3. Western blot analysis of CIRP protein expression in NIH3T3 cells upon cold shock at $32^{\circ} \mathrm{C}$ where $\beta$-actin was utilized as a loading control. (A) CIRP band in one immunoblot at the times and temperatures indicated. $(B)$ Average CIRP protein expression levels at the times and temperatures indicated $( \pm S D)$ following densitometry analysis of triplicate biological immunoblot analysis. marginally (Fig. 2D). However, beyond $6 \mathrm{~h}$ the levels of the long 5'-UTR did not decrease as observed for the open reading frame and combined $5^{\prime}$-UTR transcripts, but rather continued to increase, reaching a maximum level approximately twofold higher than that of the control $12 \mathrm{~h}$ posttemperature downshift. Further, the amount of the long 5 '-UTR increased at a more-or-less steady rate during the first $12 \mathrm{~h}$ of cold shock and this elevated level was then maintained until $24 \mathrm{~h}$ post-temperature downshift (Fig. 2D). As the long $5^{\prime}$-UTR profile did not follow the open reading frame of the combined profile this suggests that it is the short $5^{\prime}$-UTR that is more prevalent and dominates in the combined profile. It is interesting to note that in the combined profile (Fig. 2C) the levels of $5^{\prime}$-UTR begin to increase slightly (but significantly) after $24 \mathrm{~h}$ relative to 12 $\mathrm{h}$, which suggests that the levels of the long $5^{\prime}$-UTR begin to become more prevalent at this stage.

\section{CIRP long 5'UTR mRNA transcripts are stabilized at $32^{\circ} \mathrm{C}$ compared with $37^{\circ} \mathrm{C}$}

We also investigated the effect of temperature on the halflife of the CIRP transcripts using $q$ RT-PCR. Temperature reduction appeared to increase the stability of $\beta$-actin mRNA, this mRNA having a half-life of $10.4 \mathrm{~h}$ at $37^{\circ} \mathrm{C}$ and $15.8 \mathrm{~h}$ at $32^{\circ} \mathrm{C}$, thus resulting in an approximate 1.5 fold increased half-life at the lower temperature (Fig. 4A). On the other hand, temperature reduction had less of an effect on the stability and turnover rate of the combined CIRP $5^{\prime}$-UTR mRNAs as determined by $q$ RT-PCR (Fig. $4 \mathrm{~B}, \mathrm{C})$. At both $37^{\circ} \mathrm{C}(13.9 \mathrm{~h})$ and $32^{\circ} \mathrm{C}(15.9 \mathrm{~h})$ the combined $5^{\prime}$-UTR mRNA half-life was similar following actinomycin D addition (which was added $24 \mathrm{~h}$ after cold shock) suggesting that unlike $\beta$-actin mRNA cold stress has, at best, a marginal influence on the stability of the combined mRNA half-life. Conversely, as in the case of the $\beta$-actin mRNA, the rate of turnover of the long harboring CIRP $5^{\prime}$-UTR mRNA was decreased at $32^{\circ} \mathrm{C}$ relative to that observed at $37^{\circ} \mathrm{C}$ with a half-life of $9.5 \mathrm{~h}$ at $37^{\circ} \mathrm{C}$, which was increased to $14.7 \mathrm{~h}$ at $32^{\circ} \mathrm{C}$ resulting in a 1.6 -fold increase in stability at the lower temperature (Fig. 4). Therefore, at $37^{\circ} \mathrm{C}$ the long $5^{\prime}$-UTR mRNA is short lived compared with the combined $5^{\prime}$-UTR mRNA profile; however at $32^{\circ} \mathrm{C}$ the half-lives are similar.

\section{The CIRP long 5'-UTR exhibits IRES-like activity but translational efficiency is not enhanced upon cold shock}

Previous studies suggested that the 5 ' leader sequence of the cold-shock induced $R b m 3$ contains an IRES that is more active in some cell types at $32^{\circ} \mathrm{C}$ (Chappell et al. 2001; Chappell and Mauro 2003), although this has now been attributed to a cloning artifact. We therefore investigated whether the long and/or short CIRP 5'-UTRs exhibited 

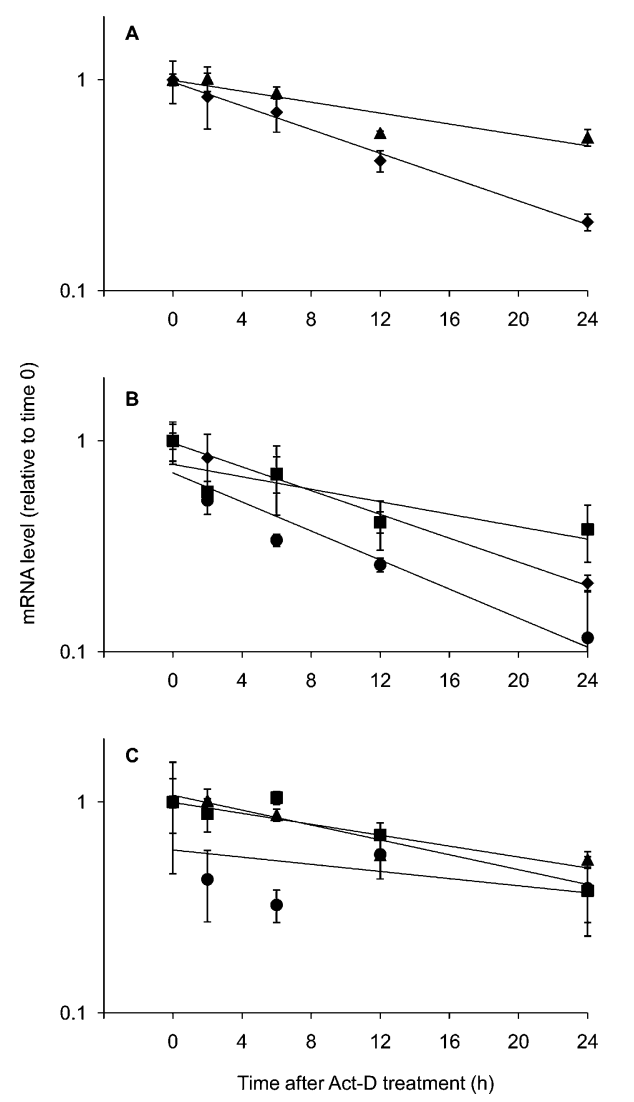

FIGURE 4. Half-life and stability determination of $\beta$-actin and CIRP long and combined $5^{\prime}$-UTRs mRNAs at 37 and $32^{\circ} \mathrm{C}$. Exponentially growing NIH-3T3 cells were cultured at 37 or $32^{\circ} \mathrm{C}$ for $24 \mathrm{~h}$ prior to the addition of actinomycin D $(5 \mu \mathrm{g} / \mathrm{mL})$. Subsequently, total RNA was isolated at $0,2,6,12$, and $24 \mathrm{~h}$ and the level of Cirp-5'UTR long, Cirp-5'UTR combined, and $\beta$-actin mRNA determined. (A) Exponential decay curves of $\beta$-actin mRNA at $37(\bullet)$ and $32^{\circ} \mathrm{C}(\mathbf{\Delta}),(B)$ decay curves of all three mRNAs at $37^{\circ} \mathrm{C}$ (actin $\bullet$ combined $5^{\prime}$-UTR $\boldsymbol{\square}$, long $5^{\prime}$-UTR $\bullet$ ), and $(C) 32^{\circ} \mathrm{C}$ (actin $\boldsymbol{\Lambda}$, combined $5^{\prime}$-UTR $\mathbf{\square}$, long $5^{\prime}$-UTR $\bullet$ ). All data shown are the means of triplicate experiments \pm SD. Half-life $\left(t_{1 / 2}\right)$ was calculated by fitting two-parameter exponential decay curves as described in the Materials and Methods section. For further details see the text.

IRES-like activity. In silico analysis of the CIRP 5'-UTR using the freeware UTRscan software package did not reveal the presence of any known structural or sequence features. We therefore utilized the previously described dicistronic reporter gene system of Willis and colleagues (Stoneley et al. 1998; Subkhankulova et al. 2001) to determine whether the long and short CIRP 5'-UTRs could initiate cap-independent translation. This system (pRF) allows for the expression of two reporter genes from one mRNA, the first (renilla luciferase) by cap-dependent translation, and the second (firefly luciferase) by capindependent (IRES-mediated) translation (Fig. 5A). A comparison of the ratio of firefly to renilla luciferase expression in the presence and absence of a putative IRES sequence can be suggestive of IRES activity. For this purpose the CIRP long (pRF-L) and short (pRF-S) 5'-UTRs were cloned into the intercistronic region between the renilla and firefly luciferase cistrons described in the pRF system.

As the $c-m y c$ IRES has previously been shown to be active, yield one dicistronic mRNA, and exhibit enhanced activity at $33^{\circ} \mathrm{C}$ relative to $37^{\circ} \mathrm{C}$ in NIH-3T3 cells (Chappell et al. 2001), we used this (pRMF) and the pRF plasmid lacking any IRES as controls. Although the activity of the $c-m y c$ IRES has been reported to be enhanced in 3T3 cells at $33^{\circ} \mathrm{C}$, the activity of the IRES in $3 \mathrm{~T} 3$ cells at physiological temperature is low (Stoneley et al. 1998), and therefore, this system acts as both a negative and positive control at the differing temperatures. As a further control and test of transfection efficiency, cells were co-transfected with a plasmid that expressed $\beta$-galactosidase.

Transfection of NIH-3T3 cells with the pRMF $c-m y c$ IRES plasmid DNA confirmed that the $c$-myc IRES was more active in cells cultured at $32^{\circ} \mathrm{C}$ than those cultured at $37^{\circ} \mathrm{C}$ (Fig. 5B). However, while the ratio of firefly to renilla expression was previously reported to be increased three- to fourfold at $33^{\circ} \mathrm{C}$ relative to that at $37^{\circ} \mathrm{C}$ in the presence of the $c-m y c$ IRES in NIH-3T3 cells, here we observed an approximate twofold increase (Fig. 5B). This is most likely explained by the difference in the experimental approaches. We note that the ratio of firefly to renilla expression from the $c-m y c$ IRES containing plasmid appears to be lower at $37^{\circ} \mathrm{C}$ than the control pRF plasmid, however, this reduction was not statistically significant and in other experiments a reduction was not observed (data not shown).



FIGURE 5. Functional analysis of the long (pRF-L) and short (pRFS) CIRP 5'-UTRs by transient transfection. The long and short $5^{\prime}$-UTRs of CIRP mRNA were $(A)$ cloned into the pRF bicistronic expression vector and $(B)$ cotransfected into NIH-3T3 with a control $\beta$-galactosidase plasmid. The relative firefly to renilla luciferase expression is shown after normalization to control $\beta$-galactosidase expression. The pRF vector was used as a negative control, while the pRMF vector containing the cmyc IRES in the intercistronic region was used as a positive control. Transfected cells were grown under either normothermic $\left(37^{\circ} \mathrm{C}\right.$, gray) or hypothermic $\left(32^{\circ} \mathrm{C}\right.$, black) growth conditions and assayed for luciferase activity $24 \mathrm{~h}$ posttransfection. For further details see the text. 
When transfected into NIH-3T3 cells, the presence of the long CIRP 5'-UTR in the intercistronic region of the dual luciferase plasmid (pRF-L) resulted in an approximate four- to fivefold increase in firefly luciferase expression above background (pRF) levels (Fig. 5B). This suggests that the long $5^{\prime}$-UTR is capable of acting as an IRES module of modest activity in this cell line, initiating translation via a cap-independent mechanism. This four- to fivefold increase in firefly expression in the presence of the long $5^{\prime}$-UTR was observed at both 37 and $32^{\circ} \mathrm{C}$, indicating that the activity was not temperature responsive. Importantly, the increase in the firefly to renilla luciferase was not the result of decreased renilla expression or increased firefly message expression with the relative levels of each message remaining the same. When the Rbm3 5' leader sequence was previously cloned into the intercistronic region of the pRF reporter gene expression system, this resulted in decreased translation of renilla luciferase relative to that observed from pRF (Chappell et al. 2001). The presence of the long CIRP 5'-UTR in the intercistronic region did not significantly affect the expression of the upstream cistron (renilla), which was statistically unchanged in all constructs studied ( $\mathrm{pRMF}, \mathrm{pRF}-\mathrm{L}, \mathrm{pRF}-\mathrm{S}$ ) relative to the $\mathrm{pRF}$ control. The presence of the long and short CIRP $5^{\prime}$-UTRs does not therefore appear to interfere with either mRNA stability or translation of the upstream renilla cistron. The presence of the short CIRP 5'-UTR in the intercistronic region of the dual luciferase plasmid (pRF-S) also resulted in firefly expression levels greater than background in NIH-3T3 cells (Fig. 5B), although the increase was approximately half that observed in the presence of the long 5 '-UTR.

In order to further investigate the possibility of the short or long 5'-UTRs containing IRESs, we inhibited the translation of the first renilla cistron by use of a strong hairpin near the $5^{\prime}$ cap and monitored the expression levels of both cistrons. The presence of IRES activity should allow translation of the second cistron in an unimpaired manner in the presence of the hairpin while translation of the first cistron should be severally hampered. As expected, the presence of the hairpin resulted in a dramatic decrease in the expression level of the first cistron (renilla) from the pHrpRMF and CIRP short and long 5'-UTR containing vectors (Fig. 6A). The presence of the CIRP long $5^{\prime}$-UTR gave more-or-less equivalent second cistron expression compared with that observed in the absence of the hairpin and significantly above those in the absence of the long $5^{\prime}$-UTR (Fig. 6B). On the other hand, when the CIRP short $5^{\prime}$-UTR was investigated in this system, second cistron expression was compromised by the presence of the hairpin (Fig. 6B). These results suggest that the long CIRP $5^{\prime}$-UTR exhibits properties consistent with the presence of an IRES, while the short CIRP 5'-UTR does not. Perhaps disappointingly the data show that conditions of mild hypothermia do not appear to enhance the efficiency of the putative IRES and we note that both first and second
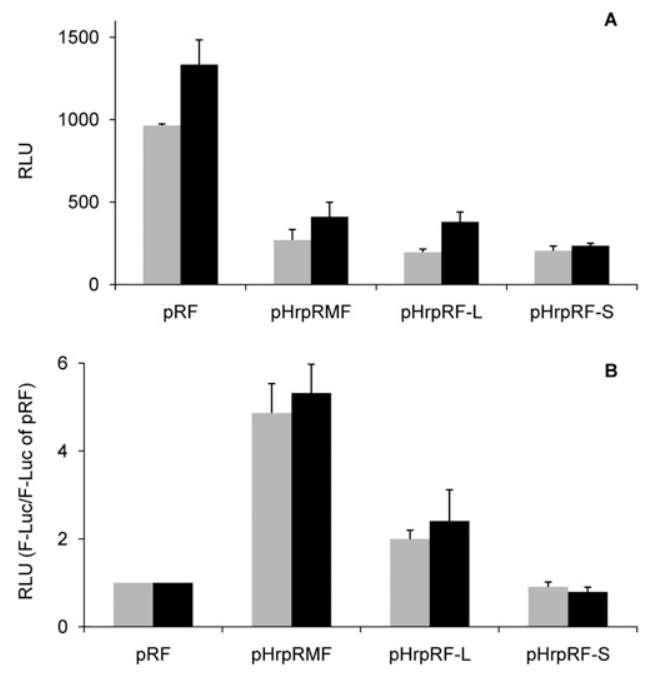

FIGURE 6. The effect of a strong hairpin near the $5^{\prime}$ cap on the expression of the second cistron in CIRP $5^{\prime}$-UTR containing bicistronic constructs at 37 (gray) and $32^{\circ} \mathrm{C}$ (black). (A) Determination of first cistron renilla luciferase expression in the pRF control plasmid and hairpin containing pHrpRMF, pHrpRF-L, and pHrpRF-S showed that the hairpin dramatically reduces expression levels of the first cistron. (B) Second cistron firefly expression was unhindered by the presence of the hairpin from the $c-m y c$ containing control vector (pHrpRMF) and the CIRP long 5'-UTR containing vector (pHrpRF$\mathrm{L})$, resulting in expression levels significantly enhanced above those in the absence of the IRES. On the other hand, the hairpin prevented firefly expression from the CIRP short 5'-UTR (pHrpRF-S, B). All data shown are the means of triplicate experiments \pm SD.

cistron protein expressions are increased at $32^{\circ} \mathrm{C}$, relative to that observed at $37^{\circ} \mathrm{C}$.

We note that the data shown in Figures 5 and 6 with regard to the $m y c$ IRES might appear to be contradictory. While Figure 5B suggests that the long $5^{\prime}$-UTR acts as a better IRES than the myc IRES, the data shown in Figure $6 \mathrm{~B}$, whereby a hairpin is inserted before the first cistron to impair cap-dependent translation, suggest that the strongest second cistron expression level relative to the first is given by the myc IRES (and hence this is the best IRES). It is difficult to explain this discrepancy unless the ability of the long UTR to recruit translation machinery has a reliance on the accessibility of the cap-structure or an interaction between the cap and the UTR element and potentially other IRES trans acting factors.

There is much debate in the literature with regard to the validity of a number of reported IRESs with suggestions that cryptic promoter or splicing events actually account for the proposed IRES activity of several putative IRESs (Baranick et al. 2008). We therefore undertook rigorous analysis of the long CIPR 5'-UTR to rule out the possibility that the enhanced firefly luciferase expression, in the presence of the long and short CIRP 5'-UTRs, was the result of a monocistronic mRNA being produced by a cryptic promoter, an unpredictable splicing event, or mRNA fragmentation (Fig. 7). Initially we used the 
A
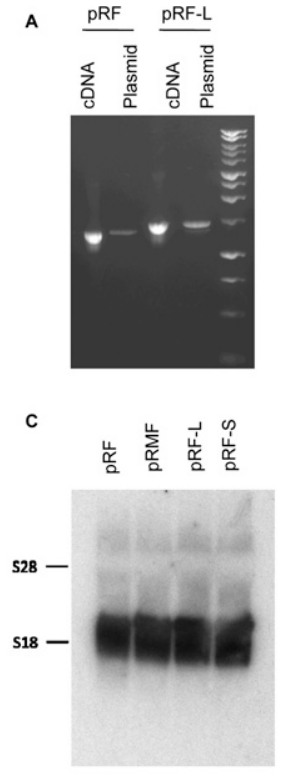

E

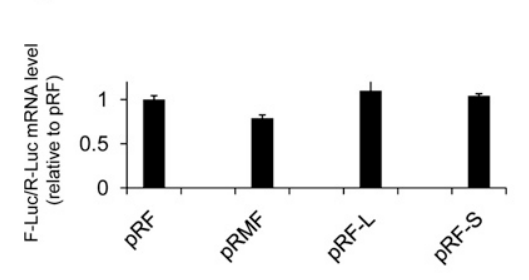

B

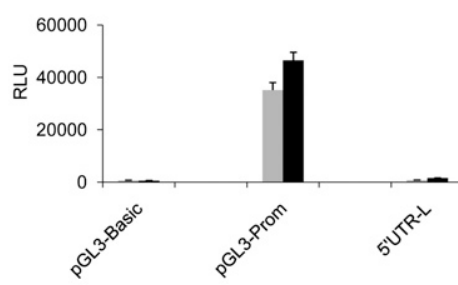

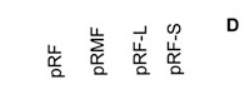
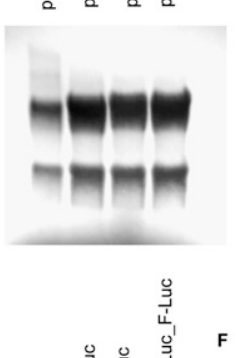

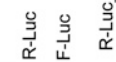

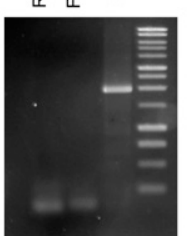

FIGURE 7. Confirmation that the CIRP long $5^{\prime}$-UTR does not result in aberrant splicing events or have promoter activity. (A) RT-PCR using a primer upstream of the pRF intron shows only the bicistronic mRNA is present and no aberrant splicing products are detected from the long $5^{\prime}$-UTR transfected cells or pRF controls. $(B)$ Cloning of the long $5^{\prime}$-UTR into a promoterless vector results in a very small amount of activity that does not account for the increase in expression of the downstream cistron. (C) Northern analysis using a firefly specific probe shows identical profiles for control (pRF, pRMF) and test (pRFL, pRF-S) samples. $(D)$ Loading control for Northern blots shown in $C$. (E) The ratio of firefly to renilla mRNA transcript level as determined by $q$ RT-PCR in the presence of the short (pRF-S) or long (pRF-L) CIRP 5'-UTR in the intercistronic region of the pRF expression vector. $(F)$ A normal PCR confirming that a dicistronic message of the correct size is generated from pRF-L and that fulllength renilla and firefly open reading frames are produced. For further details see the text.

recently reported RT-PCR method reported by Van Eden and colleagues to detect aberrant splicing or processing of the bicistronic pre-mRNA using a specific primer $5^{\prime}$ of the pRF intron (Van Eden et al. 2004). Using this approach no unexpected aberrant splicing was detected and only the bicistronic product was detected for both the control pRF and long CIRP 5'-UTR (Fig. 7A). Northern blotting with a firefly specific probe also gave more-or-less identical profiles for all constructs investigated including the previously well-characterized pRF (Fig. 7C,D). Conventional RT-PCR confirmed that a dicistronic message of the correct size was generated and that full-length renilla and

firefly open reading frames were produced (Fig. 7F). $q$ RTPCR showed that renilla luciferase normalized firefly mRNA expression levels were comparable from all the plasmids utilized in this study, including a direct comparison between the levels detected from the control pRF plasmid lacking the CIRP 5'-UTRs, the pRMF plasmid and those containing the cloned $5^{\prime}$-UTRs (Fig. 7E). Together these data substantiate the claim that increased firefly expression is not due to increased levels of firefly mRNA compared with renilla mRNA as a result of unusual splicing events or the production of monocistronic firefly mRNA. Finally, we also tested whether the long $5^{\prime}$-UTR exhibited any promoter activity in a promoterless vector. When the long $5^{\prime}$-UTR was cloned into a promoterless vector there was a very small enhancement of reporter gene activity, however the level of this activity was too small to account for the increase in protein expression reported here and not significant at $32^{\circ} \mathrm{C}$ (Fig. 7B).

\section{The activities of the CIRP long and short $5^{\prime}$-UTRs do not respond to hypoxic conditions}

Recent reports show that the expression of Rbm3 and CIRP is induced in response to hypoxic conditions (Wellmann et al. 2004). The effect of hypoxia on the activity of both the long and short CIRP 5'-UTRs was therefore investigated in $\mathrm{NIH}-3 \mathrm{~T} 3$ cells. The results showed that growth of NIH-3T3 cells at $37^{\circ} \mathrm{C}$ under conditions of normoxia or hypoxia $(1 \%$ oxygen) had no effect on the efficiency of either the long or short CIRP $5^{\prime}$-UTR in terms of firefly expression (Fig. 8). The translation of the long and short CIRP 5'-UTR containing mRNAs did not, therefore, appear to be affected by mild hypothermic or hypoxic conditions in NIH-3T3 cells, but to be equally efficient at initiating firefly luciferase mRNA translation under culture conditions of normoxia or $1 \%$ oxygen.

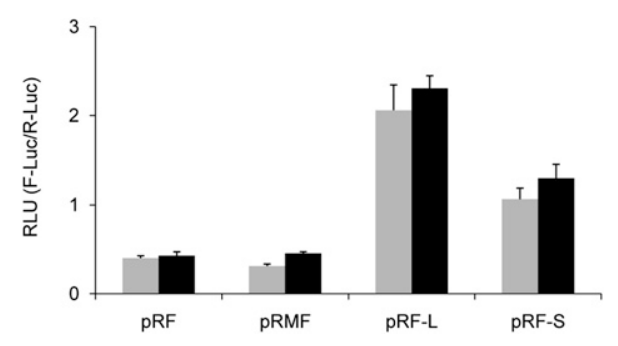

FIGURE 8. Functional analysis of the long (pRF-L) and short (pRFS) CIRP 5'-UTRs in response to hypoxia by transient transfection. NIH-3T3 cells transfected as described in Figure 4 were grown under either normoxic (gray) or hypoxic (black) conditions $\left(1 \% \mathrm{O}_{2}\right)$ at $37^{\circ} \mathrm{C}$ and assayed for luciferase activity $24 \mathrm{~h}$ post-transfection. The ration of firefly to renilla luciferase expression is shown after normalization to control $\beta$-galactosidase expression. All data shown are the means of triplicate experiments \pm SD. For full details see the text. 
The full-length CIRP long $5^{\prime}$-UTR is required for maximal activity at both 37 and $32^{\circ} \mathrm{C}$

As the presence of the long CIRP 5'-UTR in the pRF intercistronic region consistently resulted in enhanced downstream firefly luciferase gene expression relative to the short 5'-UTR, and exhibits IRES-like activity, we undertook unidirectional analysis of the long $5^{\prime}$-UTR to investigate any modular elements. Sequential deletions of $10 \mathrm{nt}$ were undertaken to yield three new fragments, which were cloned into the intercistronic region and transfected into NIH-3T3 cells. As expected, sequential deletion did progressively reduce the activity of the long $5^{\prime}$-UTR so that the activity of the short $5^{\prime}$-UTR was ultimately achieved (Fig. 9). In fact, deletion of the first $10 \mathrm{nt}$ from the long $5^{\prime}$-UTR was sufficient to reduce the activity to that of the short 5'-UTR (Fig. 9).

\section{DISCUSSION}

It is well established that the general response of prokaryotic and eukaryotic systems to temperature downshift involves the attenuation of transcription and translation (Fujita 1999; Phadtare et al. 1999; Ulusu and Tezcan 2001; Golovlev 2003; Gualerzi et al. 2003; Homma et al. 2003; Weber and Marahiel 2003; Giuliodori et al. 2004; Phadtare 2004; Murata et al. 2005), except in the case of a select number of cold-shock proteins whose synthesis continues or is up-regulated (Ermolenko and Makhatadze 2002). The exact role of cold-shock proteins is currently unknown, however, it is generally agreed that one major role is to ensure accurate and enhanced translation of specific mRNAs at low temperatures (Sahara et al. 2002). Indeed, the major cold-shock protein expressed in E. coli at $10^{\circ} \mathrm{C}$ is

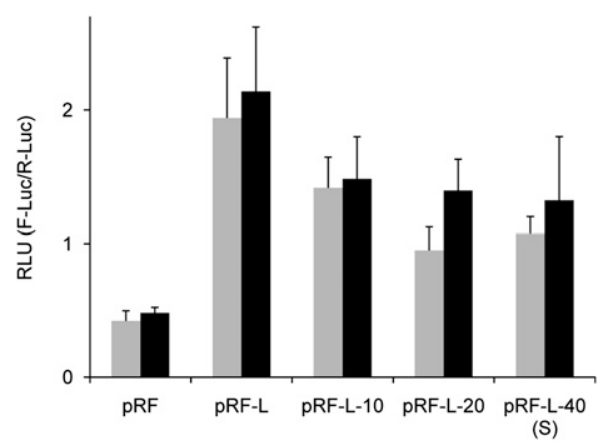

FIGURE 9. $5^{\prime}$ Unidirectional deletion analysis of the long CIRP $5^{\prime}$-UTR. Ten nucleotide truncated fragments of the long $5^{\prime}$-UTR were generated by PCR and subcloned into the pRF bicistronic vector. Subsequently, the generated constructs were transfected into NIH-3T3 cells and grown at normothermic $\left(37^{\circ} \mathrm{C}\right.$ gray) or hypothermic $\left(32^{\circ} \mathrm{C}\right.$ black) temperatures and the luciferase activity determined $24 \mathrm{~h}$ posttransfection. The firefly to renilla luciferase expression ratio is shown after normalization to control $\beta$-galactosidase expression. The pRF vector was used as a control. All data shown are the means of triplicate experiments \pm SD. For further details see the text. cold-shock protein A (CspA), an RNA binding protein (Jones et al. 1987; Golovlev 2003). CspA mRNA contains an unusually long $5^{\prime}$-UTR, which plays a vital role in stabilizing the mRNA and enhancing translation efficiency at low temperature (Fang et al. 1997; Gualerzi et al. 2003; Giuliodori et al. 2004). We have shown here that there are three major CIRP transcripts generated with different transcription start sites that result in varied-length $5^{\prime}$-UTRs, and that the level of each of these transcripts is regulated in response to temperature and time. In addition, we show that the long CIRP $5^{\prime}$-UTR has different turnover rates at 37 and $32^{\circ} \mathrm{C}$, respectively, while the half-life of the combined UTRs is only marginally influenced by temperature. Finally, the long CIRP 5'-UTR exhibits IRES-like activity, but this activity is not responsive to temperature or hypoxia.

Previous reports have shown that both CIRP transcription and translation are induced under subphysiological temperature conditions of $25-32^{\circ} \mathrm{C}$ (Fujita 1999), and our findings are in agreement with this. It has also been shown that CIRP mRNA stability is not enhanced at lower temperatures, unlike CspA mRNA in E. coli (Nishiyama et al. 1998a,b). We show here that upon temperature downshift to $32^{\circ} \mathrm{C}$ at least two discrete CIRP $5^{\prime}$-UTRs with different transcription start sites and stabilities are preferentially generated, and that these are expressed in a timedependent manner. Indeed, RACE analysis of the $32^{\circ} \mathrm{C}$ sample after $6 \mathrm{~h}$ suggests the presence of further discrete transcripts of a greater length than the long $5^{\prime}$-UTR described here (see Fig. 1B), however despite numerous attempts it was not possible to characterize or confirm these. A search of publicly available expressed sequence tags suggests at least one additional 5'-UTR may be expressed that is extended a further $21 \mathrm{nt}$ in length upstream of the long 5'-UTR reported here, generating a 5'-UTR $146 \mathrm{nt}$ in length (Fig. 1C). Further, it has previously been proposed that alternative pre-mRNA splicing is a likely mechanism by which mammalian cells regulate gene expression upon cold shock (Sonna et al. 2002). We cannot rule out the possibility of splice variants or other transcription start sites resulting in a more heterogeneous population of CIRP $5^{\prime}$-UTRs being present than those reported in this study. However, although further $5^{\prime}$-UTRs may be present, the $5^{\prime}$-UTRs described here appear to be the major transcripts generated at $32^{\circ} \mathrm{C}$ (the long and short) and $37^{\circ} \mathrm{C}$ (control UTR), and any others are likely to be of low abundance. Further, the stability of the long transcript is enhanced at $32^{\circ} \mathrm{C}$, while the stability of the combined $5^{\prime}$-UTRs is similar at both 37 and $32^{\circ} \mathrm{C}$, consistent with the previous reports that CIRP open reading frame mRNA is not stabilized at $32^{\circ} \mathrm{C}$ (Nishiyama et al. 1998a,b).

Although neither the short nor the long $5^{\prime}$-UTR was detected in control $37^{\circ} \mathrm{C}$ samples by the RACE approach, these are clearly present, although at significantly reduced levels, at physiological temperature culture conditions as 
shown by PCR analysis. As RACE analysis will only work on capped 5' transcripts, all must be capped, ruling out the possibility of the shorter transcripts being derived from the truncation of longer transcripts. The data and expression profiles of the three characterized transcripts support the hypothesis that the levels of these major transcripts control CIRP protein expression at 37 and $32^{\circ} \mathrm{C}$. Accordingly, the mechanism controlling CIRP protein expression involves both transcriptional and translational regulation. As the major transcript at $37^{\circ} \mathrm{C}$ is that starting immediately after the ATG translational start codon, the major transcript produced at this temperature presumably does not encode for full-length CIRP and must be either inactive or lead to the synthesis of a truncated protein via a downstream AUG start codon. Analysis of the $37^{\circ} \mathrm{C}$ cDNA transcript (Fig. 1) reveals that the first potential ATG is out of frame and is located near the $5^{\prime}$ end of the $37^{\circ} \mathrm{C}$ transcript. If this is a true translation start site, the frame shift would lead to the synthesis of a short 33 amino acid peptide before terminating at a stop codon resulting in the synthesis of a variant protein. Our immunoblot analysis did not detect the presence of any truncated protein variants; however, this is not surprising as the antibody used in this study recognizes the C-terminal of full-length CIRP. The low expression levels of CIRP observed at $37^{\circ} \mathrm{C}$ must therefore be synthesized via translation of the relatively low levels of mRNA containing either the short or long 5'-UTR, whose transcription start sites are upstream of the ATG start codon. Alternative transcription start sites therefore regulate the levels of CIRP expressed at $37^{\circ} \mathrm{C}$ and maintain them at low levels. Such control of gene expression via alternative 5'-UTRs or first exons has previously been reported in the control of a number of systems and genes (Tan et al. 2005; Hughes 2006).

Our data also show that the expression levels of the long and combined $5^{\prime}$-UTR transcripts are regulated over time at $32^{\circ} \mathrm{C}$ and that at this temperature the stability of the long $5^{\prime}$-UTR is increased. The initial response at the transcriptional levels is to up-regulate the levels of the combined $5^{\prime}$-UTR transcripts within the first $6 \mathrm{~h}$, however beyond $6 \mathrm{~h}$ the combined $5^{\prime}$-UTR level decreases, while the levels and stability of the longer $5^{\prime}$-UTR is increased at $32^{\circ} \mathrm{C}$. As the long $5^{\prime}$-UTR only harbors moderate IRES activity, once the cells begin to acclimatize and appropriate levels of CIRP are accumulated, presumably this transcript is sufficient and optimal for maintaining the required levels of CIRP protein.

We note that the longest CIRP 5'-UTR identified in this study was significantly shorter than the previously characterized Rbm3 5'-UTR (Chappell et al. 2001; Chappell and Mauro 2003) or CspA 5'-UTR (Mitta et al. 1997), each of which enhances mRNA translation efficiency at low temperature. However, recent reports have shown that the $R b m 3$ IRES activity is the result of cloning and is not a true IRES (Baranick et al. 2008). Here we have shown that relatively short sections within the $5^{\prime}$-UTR can form control elements, as others have done so previously (Mignone et al. 2002), and sort to determine if an IRES mechanism was involved in the control of CIRP mRNA translation. Our results suggest that the long 5 '-UTR exhibits IRES-like activity, resulting in a several-fold increase in translation above background levels when cap-dependent translation is compromised via the presence of a hairpin structure. Internal translation initiation via IRES modules when global cap-dependent translation is attenuated has now been reported for a number of mRNAs during conditions of stress and it is thought that as many as $10 \%$ of cellular mRNAs contain IRESs (Mitchell et al. 2005).

It was disappointing that the IRES-like activity of the CIRP long $5^{\prime}$-UTR was not shown to be temperature sensitive, exhibiting equal efficiency at 37 and $32^{\circ} \mathrm{C}$. Despite this, the actual level of the long transcript is regulated in response to temperature as discussed above, and therefore expression of CIRP appears to be regulated at two levels, the first at the transcriptional level and the second at the translational level. Further, truncation of the long $5^{\prime}$-UTR by $10 \mathrm{nt}$ was sufficient to reduce the activity to that of the short UTR, suggesting that the entire length is required for the activity. The data therefore support the hypothesis that the switch in transcript levels, stability, and mechanism of mRNA translation is crucial in maintaining adequate CIRP expression over extended periods of cellular stress at mild hypothermic temperatures. An alternative conclusion is that the long 5'-UTR imparts conditionality to CIRP expression, such that the long transcript is utilized more efficiently during recovery when the temperature returns to $37^{\circ} \mathrm{C}$.

Finally, as reported above, upon temperature downshift there is an increase in the levels of the open reading frame transcript and both the combined transcript levels and long $5^{\prime}$-UTR transcripts. The control mechanism by which the levels of mRNAs generated from the different transcription start sites is regulated remains to be elucidated, but is clearly important in controlling CIRP protein expression. One possible explanation for this is the presence of alternative promoters, one of which is more active at $37^{\circ} \mathrm{C}$ and results in the truncated transcript, which starts downstream from the open reading frame ATG start codon, and one (or more), which is activated upon cold shock and results in the two longer transcripts. Indeed, such a mechanism of control involving alternative promoters, one of which is cold sensitive, has previously been described in E. coli. In this example the levels of the mRNA coding for the essential protein initiation factor 1 in $E$. coli have been shown to be increased upon cold shock as a result of transcriptional activation of an alternative promoter (Ko et al. 2005). Indeed, the Genomatrix PromoterInspector software program (www.genomatrix.de) predicts the presence of one promoter region in the spliced $1891 \mathrm{bp}$ intron sequence of CIRP that might be responsible for the major transcript observed at $37^{\circ} \mathrm{C}$ and a further promoter region 
immediately upstream of the long transcript start site, which could account for the transcripts observed at $32^{\circ} \mathrm{C}$ (data not shown). Furthermore, additional promoter regions are predicted further upstream of the $32^{\circ} \mathrm{C}$ transcription start sites. We are currently investigating this natural progression of CIRP regulation, to fully elucidate the transcriptional control of its expression.

\section{MATERIALS AND METHODS}

\section{Materials}

All materials were sourced from Sigma-Aldrich, unless otherwise stated. Primers used throughout the study are detailed in Table 1.

\section{Cell culture}

Mouse NIH-3T3 fibroblast (ECACC No. 93061524) cells were sourced from the European Collection of Cell Cultures (ECACC) and routinely cultured in Dulbecco's Modified Eagle Medium (DMEM) (Invitrogen) supplemented with $200 \mathrm{mM} \mathrm{L}$-glutamine, $500 \mu \mathrm{M}$ glutamic acid, $500 \mu \mathrm{M}$ asparagine, $30 \mu \mathrm{M}$ adenosine, $30 \mu \mathrm{M}$ guanosine, $30 \mu \mathrm{M}$ cytidine, $30 \mu \mathrm{M}$ uridine, $10 \mu \mathrm{M}$ thymidine, $1 \%$ nonessential amino acids (Invitrogen), and $10 \%$ dialyzed fetal bovine serum (PAA Laboratories Ltd.). Cells were grown at $37^{\circ} \mathrm{C}$ in a $5 \% \mathrm{CO}_{2}$ atmosphere unless indicated otherwise.

\section{RNA extraction and reverse transcription}

RNA extraction from cell pellets was undertaken using an RNeasy Mini Kit (Qiagen) according to the manufacturer's instructions. Total cDNA was synthesized from $2 \mu \mathrm{g}$ of total RNA using Thermo-X Reverse Transcriptase (Invitrogen) according to the manufacturer's instructions. Briefly, $1 \mathrm{nmol}$ of random hexamers (Ambion) were hybridized by incubation for $10 \mathrm{~min}$ at $25^{\circ} \mathrm{C}$ and extended by incubation for $30 \mathrm{~min}$ at $65^{\circ} \mathrm{C}$ in the presence of 100 $\mathrm{U}$ of Thermo-X Reverse Transcriptase, $50 \mu \mathrm{M}$ dNTP mix, and 40U of RNase inhibitor (Ambion). Subsequent amplification of target cDNA was performed using $1 \mu \mathrm{L}$ of generated cDNA mix. Generally, PCR reaction volumes were $50 \mu \mathrm{L}$ and contained 200 $\mu \mathrm{M}$ dNTPs, $400 \mathrm{nM}$ of the appropriate primers (Table 1), $2.5 \mathrm{U}$ of Taq DNA polymerase (Promega), and $5 \mu \mathrm{L}$ of 10X PCR buffer. The amplification reactions were initiated with a preheating step at $94^{\circ} \mathrm{C}$ for $2 \mathrm{~min}$ and cycling conditions were as follows: $94^{\circ} \mathrm{C}$ for $30 \mathrm{sec}$, annealing at $58^{\circ} \mathrm{C}$ for $30 \mathrm{sec}$, and polymerization at $72^{\circ} \mathrm{C}$ for $1 \mathrm{~min}$, followed by a final extension step at $72^{\circ} \mathrm{C}$ for $10 \mathrm{~min}$.

TABLE 1. Detailed description of the primers utilized in this study

\begin{tabular}{|c|c|c|}
\hline Primer & Sequence $\left(5^{\prime} \rightarrow 3^{\prime}\right)$ & Primer description \\
\hline \multicolumn{3}{|c|}{ Primes used to map transcription initiation sites of Cirp using RLM-RACE } \\
\hline 5' RACE outer primer $(\mathrm{F})$ & GCTGATGGCGATGAATGAACACTG & Sense for RLM-RACE first PCR \\
\hline Cirp-NS-OTR (R) & GGGCTTTTACTCGTTGTGTGTAGC & Antisense for RLM-RACE first PCR \\
\hline 5' RACE inner primer (F) & CGCGGATCCGAACACTGCGTTTGCTGGCTTTGATG & Sense for RLM-RACE nested PCR \\
\hline Cirp-NS-INR (R) & GACTTCCСАTTCATAGCCATCATGGC & Antisense for RLM-RACE nested PCR \\
\hline \multicolumn{3}{|c|}{ Primers used for quantitative real-time PCR (RT-qPCR) } \\
\hline Cirp5'UTRL-RT (F) & GGAGTATATCAGGCGGGACT & Sense for Cirp long 5'UTR \\
\hline Cirp5'UTRS-RT (F) & TAGGAAGCTTGGGTGTGTGT & Sense for Cirp short 5'UTR \\
\hline Cirp5'UTR-RT (R) & TGTCCTTTACCACСАCСАCT & Antisense for Cirp 5'UTR \\
\hline Cirp-ORF-RT (F) & GACTCAGCTTCGACACCAAC & Sense for Cirp ORF \\
\hline$\beta$-actin-RT (F) & AGCTGAGAGGGAAATTGTGCG & Sense for $\beta$-actin ORF \\
\hline$\beta$-actin-RT (R) & GCAACGGAACCGCTCATT & Antisense for $\beta$-actin ORF \\
\hline pRF-Rluc-RT (F) & TAACGCGGCCTCTTCTTATT & Sense for Renilla Luciferase \\
\hline pRF-Rluc-RT (R) & CCATTACCAGATTTGCСТGA & Antisense for Renilla Luciferase \\
\hline pRF-Fluc-RT (F) & TTGGCAGAAGCTATGAAACG & Sense for Firefly Luciferase \\
\hline pRF-Fluc-RT (R) & GCAACTGCAACTCCGATAAA & Antisense Firefly Luciferase \\
\hline \multicolumn{3}{|c|}{ Primers used for dicistronic reporter plasmids } \\
\hline Cirp5'UTR-32-6 (F) & CGACCATCACTAGTAGGAGTGGAGTATATCAGGCGGGAC & Sense (Spel) for full-length 5'UTR cloning \\
\hline Cirp5'UTR-32-24 (F) & CGACCATCACTAGTACTCGCGCCTTAGGAAGCTTGG & $\begin{array}{l}\text { Sense }(\overline{S p e l}) \text { for full-length short 5'UTR } \\
\text { cloning }\end{array}$ \\
\hline Cirp-5'UTR (R) & ACCAACGAATTCGGCAGCCGCTGAGTCGG & $\begin{array}{l}\text { Antisense }(\underline{E c o R I}) \text { for full-length } 5^{\prime} \text { UTR } \\
\text { cloning }\end{array}$ \\
\hline Cirp-32-24-R2 & TGGCTTCCATGGGGCAGCCGCTGAGTCGG & $\begin{array}{l}\text { Antisense (Ncol) for full-length 5'UTR } \\
\text { cloning into pHrpRF plasmid }\end{array}$ \\
\hline Cirp5'UTR-L-10 (F) & CGACCATCACTAGTATATCAGGCGGGACTCTTG & Sense (Spel) used for $10 \mathrm{bp}$ \\
\hline Cirp5'UTR-L-20 (F) & CGACCATCACTAGTGGGACTCTTGCGCTCCССCT & 5 'unidirectional deletions of the Cirp \\
\hline Cirp5'UTR-L-30 (F) & CGACСATCACTAGTCGСТСССССТСGСАСТCGCGССT & 5'UTR-L \\
\hline Cirp5'UTR-L-40 (F) & CGACCATCACTAGTCGCACTCGCGCCTTAGGAAGC & \\
\hline \multicolumn{3}{|c|}{ Primers used to rule out aberrant splicing of bicistronic pre-mRNAs } \\
\hline pRF-F4 & ССTATAGTGAGTCGTATTAA & $\begin{array}{l}\text { Sense for pRF, upstream of the TSS of } \\
R-L u c_{-} F-L u c\end{array}$ \\
\hline
\end{tabular}

Note: Further details are provided in the text. Underlined entries show restriction enzyme cloning sites. 
PCR products were analyzed on $2 \%$ agarose gels and visualized with ethidium bromide under UV light.

\section{5' RNA ligase-mediated rapid amplification of CDNA ends (RLM-RACE)}

Transcription initiation sites of CIRP mRNA were mapped by PCR using the FirstChoice RLM-RACE kit (Ambion) according to the manufacturer's instructions, in which only authentic $5^{\prime}$ capped mRNAs are selectively amplified by nested PCR. This procedure was carried out using $10 \mu \mathrm{g}$ of total RNA isolated from mouse NIH-3T3 cells either grown at $37^{\circ} \mathrm{C}$ or cold shocked at $32^{\circ} \mathrm{C}$ for the indicated time points. The primers used for first and nested PCRs are described in detail in Table 1.

\section{DNA cloning and sequencing}

Following RACE-nested PCR, amplified fragments were purified using the Wizard PCR preps DNA purification system (Promega) and subsequently TA-cloned into the pGEM-T Easy Vector System (Promega). Plasmid DNA was purified using a QiaFilter Plasmid Maxi kit (Qiagen) and then submitted for sequencing commercially (MWG Biotech).

\section{Construction of reporter gene expression vectors}

Full-length Cirp 5'-UTRs were amplified with Pfu DNA polymerase using the RACE cDNA mix as a template. The PCR reaction volumes $(50 \mu \mathrm{L})$ contained $200 \mu \mathrm{M}$ dNTPs, $400 \mathrm{nM}$ of appropriate primers (Table 1), $2.5 \mathrm{U}$ of $P f u$ DNA polymerase (Promega), and $5 \mu \mathrm{L}$ of $P f u$ 10X PCR buffer. The amplification reactions were denatured at $94^{\circ} \mathrm{C}$ for 2 min followed by 35 cycles $\left(94^{\circ} \mathrm{C}\right.$ for $30 \mathrm{sec}, 58^{\circ} \mathrm{C}$ for $30 \mathrm{sec}$, and $72^{\circ} \mathrm{C}$ for $\left.1 \mathrm{~min}\right)$. Amplified PCR products were purified and subjected to SpeI and EcoRI double digestion. Ultimately, pRF-L and pRF-S constructs were generated by inserting digested fragments into the SpeI and EcoRI sites of the $\mathrm{pRF}$ reporter vector. The $\mathrm{pRF}, \mathrm{pHrpRMF}$, and $\mathrm{pRMF}$ bicistronic reporter vectors were kind gifts from Professor Anne Willis (University of Nottingham). For sequential deletion analysis of the Cirp 5'-UTR, progressive $10 \mathrm{bp}$ deletions from the $5^{\prime}$ end of the longer $5^{\prime}$-UTR were amplified using $P f u$ DNA polymerase and $\mathrm{pRF}-\mathrm{L}$ plasmid as a template. The amplified fragments were purified, digested with SpeI and EcoRI, and subcloned into the pRF plasmid. The generated constructs were designated pRFL-10, pR-L-20, pRF-L-30, and pRF-L-40. To create the vectors pHrpRMF-L and pHrpRMF-S, pHrpRMF plasmid was digested with SpeI and NcoI followed by gel purification to remove the intercistronic $c-m y c$ sequence. Concurrently, forward and reverse primers that contain internal SpeI and NcoI sites, respectively (Table 1), were used to amplify Cirp 5'-UTR-L and 5'-UTR-S using pRF-L plasmid DNA as a template. The generated PCR products were purified, digested with SpeI and NcoI, and cloned into SpeI and NcoI digested pHrpRMF vector.

\section{Transient cotransfection and reporter gene analysis}

All transfection experiments were performed in triplicate using the commercially available FuGENE 6 transfection reagent (Roche). $\mathrm{NIH}-3 \mathrm{~T} 3$ cells were seeded at a density of $3 \times 10^{5}$ cells in six-well tissue culture plates and grown overnight at $37^{\circ} \mathrm{C}$ to $50-70 \%$ confluence. Prior to transfection, cells were washed with pre- warmed PBS and $4 \mathrm{~mL}$ of fresh media were added to each well. The appropriate plasmid DNA ( $1 \mu \mathrm{g}$ unless indicated otherwise) was suspended in $900 \mu \mathrm{L}$ of serum-free DMEM media followed by the addition of FuGENE 6 reagent $(6 \mu \mathrm{L})$. Transfection mixes were vortexed briefly, incubated at room temperature for $15 \mathrm{~min}$, added drop-wise to the cells, and evenly distributed by gentle agitation. A pSV- $\beta$-galactosidase vector (Promega) was included in all transfection experiments as a transfection efficiency control. The transfected cells were then incubated in a humidified atmosphere at 37 or $32^{\circ} \mathrm{C}$ under $5 \% \mathrm{CO}_{2}$ for the indicated time periods. For cold shock experiments, cells were allowed to recover at $37^{\circ} \mathrm{C}$ for $4 \mathrm{~h}$ post-transfection before shifting the temperature to $32^{\circ} \mathrm{C}$. At the time of harvesting, cells were washed twice with PBS, lysed for 15 min with the Reporter Lysis Buffer (RLB) (Promega), and harvested by scraping. The lysates were cleared by centrifugation at $20,000 \mathrm{~g}$ for $1 \mathrm{~min}$ and then assayed for luciferase and $\beta$-galactosidase activity using the Dual Luciferase Reporter Assay System or the $\beta$-Galactosidase Enzyme Assay System with Reporter Lysis Buffer (Promega), respectively. Luciferase activity was normalized to $\beta$-galactosidase activity and results are reported as the mean $\pm \mathrm{SD}$.

\section{Quantitative real time PCR and determination of mRNA half-life}

Total RNA extracted from NIH-3T3 cells grown under various culture conditions were amplified using the iScript One-Step RTPCR Kit with SYBR Green label (Bio-Rad). All quantitative realtime PCR experiments were performed on the MiniOpticon Real-Time PCR Detection System (Bio-Rad) in a $25 \mu \mathrm{L}$ volume containing $300 \mathrm{nM}$ of the appropriate primers (Table 1), $12.5 \mu \mathrm{L}$ 2X SYBR Green RT-PCR reaction mix, and $50 \mathrm{ng}$ of appropriate total RNA template. Reverse transcriptase was initially performed on the total RNA at $50^{\circ} \mathrm{C}$ for $10 \mathrm{~min}$ and the amplification protocol consisted of one cycle at $95^{\circ} \mathrm{C}$ for $5 \mathrm{~min}$ followed by 39 cycles of amplification $\left(95^{\circ} \mathrm{C}\right.$ for $10 \mathrm{sec}$ and $56^{\circ} \mathrm{C}$ for $\left.30 \mathrm{sec}\right)$, after which the reaction was melted by stepwise increase of the temperature from 56 to $95^{\circ} \mathrm{C}$. All calculations, including melting curves and crossing points (CP), were determined using the Opticon Monitor software (Bio-Rad) and normalized to $\beta$-actin mRNA expression levels as a reference gene. For determination of mRNA half-lives, exponentially growing $\mathrm{NIH}-3 \mathrm{~T} 3$ cells were cultured at 37 or $32^{\circ} \mathrm{C}$ for $24 \mathrm{~h}$ prior to the addition of actinomycin D $(5 \mu \mathrm{g} / \mathrm{mL})$. Subsequently, total RNA was isolated at $0,2,6,12$, and $24 \mathrm{~h}$ and the relative amount of Cirp-5'UTR-L, Cirp-5'UTR-S, and $\beta$-actin mRNA determined. All data shown are the means of triplicate experiments \pm SD. mRNA turnover was determined from the decay rate constant $(k)$, using the iterative curve fitting software SigmaPlot (SPSS), by fitting two-parameter exponential decay curves described by Equation 1. Subsequently, mRNA half-lives $\left(t_{1 / 2}\right)$ were calculated from the decay rate constant (Equation 2).

$$
\begin{gathered}
N=N_{0} e^{-k t}, \\
t_{1 / 2}=\ln (2) / k .
\end{gathered}
$$

To assure correct splicing of the pRF chimeric intron and to detect possible splice variants, $\sim 5 \mu \mathrm{g}$ of the total cellular RNA 
from pRF-L-transfected NIH-3T3 cells was subjected to RT-PCR using pRF-F4 forward primer located upstream of the chimeric intron and pRF-Fluc-RT-R reverse primer (Table 1) located toward the $3^{\prime}$ end of Rluc-Fluc sequence. As a control, the pRF and pRF-L plasmid DNA were used as a template in parallel PCR reactions.

\section{Protein extraction and Western blotting}

$\mathrm{NIH}-3 \mathrm{~T} 3$ cells were grown in T75 tissue culture flasks to $\sim 70 \%$ confluency and either cold shocked, by shifting growth temperature to $32^{\circ} \mathrm{C}$ for the indicated time points, or left to grow at $37^{\circ} \mathrm{C}$. Cells were then lysed with $500 \mu \mathrm{L}$ of lysis buffer $(150 \mathrm{mM}$ $\mathrm{NaCl}, 50 \mathrm{mM}$ Tris- $\mathrm{HCl}$ at $\mathrm{pH}$ 7.4, 1 mM EDTA, 1\% Triton X-100, $1 \%$ sodium deoxycholic acid, $0.1 \%$ sodium dodecylsulfate, $1 \mathrm{mM}$ PMSF, and protease inhibitor cocktail [Roche]). Total protein (15-20 $\mu$ g per well) was then separated on a 15\% tris-glycine SDSPAGE gel, transferred to polyvinylidene difluoride (PVDF) membrane, and stained with Coomassie Brilliant Blue solution R-250 to confirm equal protein loading and successful transfer. The membrane was blocked with 3\% BSA in TSB for $1 \mathrm{~h}$ and washed three times every $10 \mathrm{~min}$ with TBS-T buffer. The membrane was then incubated overnight at $4^{\circ} \mathrm{C}$ with $1 \mu \mathrm{g} / \mathrm{mL}$ of rabbit anti-CIRP polyclonal antibody (Proteintech Group, Inc.) or mouse anti- $\beta$ actin monoclonal antibody, then washed three times for $10 \mathrm{~min}$ with TBS-T buffer before incubation with the appropriate secondary antibody conjugated with horseradish peroxidise for 1 $\mathrm{h}$ at room temperature. Finally, protein bands were detected using the ECL reagent system, as per the manufacturer's instructions (GE Healthcare). All immunoblots were undertaken on individual triplicate samples and the resulting bands subjected to densitometry using the software program ImageJ.

\section{Northern blot analysis}

To test for CIRP expression, total cellular RNA was isolated from $\mathrm{NIH}-3 \mathrm{~T} 3$ cell grown at 37 or at $32^{\circ} \mathrm{C}$ for indicated time points using the RNeasy Mini Kit (Qiagen). To examine the integrity of the dicistronic transcripts of the R-luc_F-Luc, total RNA was isolated from NIH-3T3 cell transfected with $2 \mu \mathrm{g}$ of pRF, pRMF, pRF-S, or pRF-L plasmid. Subsequently, $10 \mu \mathrm{g}$ of total RNA were loaded onto a denaturing $1.2 \%$ formaldehyde agarose gel, electrophoresed in the presence of formaldehyde, and transferred to Hybond-N membranes (Amersham Pharmacia Biotech) by capillary blotting. The integrity of the RNA and the efficiency of transfer were evaluated by staining the membrane with methylene blue. Northern probes that correspond to the entire CIRP ORF or to $122 \mathrm{bp}$ of the Firefly luciferase were generated by PCR and labeled using Ready-To-Go DNA-labeling beads kit (Amersham Pharmacia Biotech) as recommended by the manufacturer. The blots were hybridized with ${ }^{32} \mathrm{P}$ labeled probes at $42{ }^{\circ} \mathrm{C}$ using $0.5 \mathrm{M}$ phosphate buffer at $\mathrm{pH} 7.2,7 \%$ SDS, and $10 \mathrm{mM}$ EDTA for $16 \mathrm{~h}$. Subsequently, blots were washed with $2 \times$ SSC buffer with $0.1 \%$ SDS for $15 \mathrm{~min}, 3 \times$ and $1 \times$ SSC with $0.1 \%$ SDS for $10 \mathrm{~min}$, twice followed by two final washes with $0.1 \%$ SSC with $0.1 \%$ SDS. The bound radioactive material was visualized by autoradiography.

\section{ACKNOWLEDGMENTS}

We thank Professor Anne Willis, University of Nottingham for providing the pRF, pRMF, and pHrpRMF plasmids utilized throughout this study, and the Saudi Arabian Government for financial support for M.B.A.-F. We also thank Dr. Anne Roobol, University of Kent, for useful discussions and immunoblot analysis. This work was partially supported by grants $\mathrm{BB} /$ C006569/1 and BB/F018908/1 from the Biotechnology and Biological Sciences Research Council (BBSRC).

Received May 12, 2008; accepted March 11, 2009.

\section{REFERENCES}

Al-Fageeh, M.B. and Smales, C.M. 2006. Control and regulation of the cellular responses to cold shock: the responses in yeast and mammalian systems. Biochem. J. 397: 247-259.

Al-Fageeh, M.B., Marchant, R.J., Carden, M.J., and Smales, C.M. 2006. The cold-shock response in cultured mammalian cells: Harnessing the response for the improvement of recombinant protein production. Biotechnol. Bioeng. 93: 829-835.

Baranick, B.T., Lemp, N.A., Nagashima, J., Hiraoka, K., Kasahara, N., and Logg, C.R. 2008. Splicing mediates the activity of four putative cellular internal ribosome entry sites. Proc. Natl. Acad. Sci. 105: 4733-4738.

Chappell, S.A. and Mauro, V.P. 2003. The internal ribosome entry site (IRES) contained within the RNA-binding motif protein 3 (Rbm3) mRNA is composed of functionally distinct elements. J. Biol. Chem. 278: 33793-33800.

Chappell, S.A., Owens, G.C., and Mauro, V.P. 2001. A 5' leader of Rbm3, a cold stress-induced mRNA, mediates internal initiation of translation with increased efficiency under conditions of mild hypothermia. J. Biol. Chem. 276: 36917-36922.

Danno, S., Nishiyama, H., Higashitsuji, H., Yokoi, H., Xue, J.H., Itoh, K., Matsuda, T., and Fujita, J. 1997. Increased transcript level of RBM3, a member of the glycine-rich RNA-binding protein family, in human cells in response to cold stress. Biochem. Biophys. Res. Commun. 236: 804-807.

Derry, J.M., Kerns, J.A., and Francke, U. 1995. RBM3, a novel human gene in Xp11.23 with a putative RNA-binding domain. Hum. Mol. Genet. 4: 2307-2311.

Dresios, J., Aschrafi, A., Owens, G.C., Vanderklish, P.W., Edelman, G.M., and Mauro, V.P. 2005. Cold stress-induced protein $\mathrm{Rbm} 3$ binds $60 \mathrm{~S}$ ribosomal subunits, alters microRNA levels, and enhances global protein synthesis. Proc. Natl. Acad. Sci. 102: $1865-1870$.

Ermolenko, D.N. and Makhatadze, G.I. 2002. Bacterial cold-shock proteins. Cell. Mol. Life Sci. 59: 1902-1913.

Fang, L., Jiang, W., Bae, W., and Inouye, M. 1997. Promoterindependent cold-shock induction of cspA and its derepression at $37^{\circ} \mathrm{C}$ by mRNA stabilization. Mol. Microbiol. 23: 355-364.

Fox, S.R., Tan, H.K., Tan, M.C., Wong, S., Yap, M.G.S., and Wang, D.I.C. 2005. A detailed understanding of the enhanced hypothermic productivity of interferon- $\gamma$ by Chinese-hamster ovary cells. Biotechnol. Appl. Biochem. 41: 255-264.

Fujita, J. 1999. Cold shock response in mammalian cells. J. Mol. Microbiol. Biotechnol. 1: 243-255.

Giuliodori, A.M., Brandi, A., Gualerzi, C.O., and Pon, C.L. 2004. Preferential translation of cold-shock mRNAs during cold adaptation. RNA 10: 265-276.

Golovlev, E.L. 2003. Bacterial cold shock response at the level of DNA transcription, translation and chromosome dynamics. Mikrobiologiia 72: 5-13.

Gualerzi, C.O., Giuliodori, A.M., and Pon, C.L. 2003. Transcriptional and post-transcriptional control of cold-shock genes. J. Mol. Biol. 331: $527-539$.

Homma, T., Iwahashi, H., and Komatsu, Y. 2003. Yeast gene expression during growth at low temperature. Cryobiology 46: 230-237.

Hughes, T.A. 2006. Regulation of gene expression by alternative untranslated regions. Trends Genet. 22: 119-122. 
Jones, P.G., VanBogelen, R.A., and Neidhardt, F.C. 1987. Induction of proteins in response to low temperature in Escherichia coli. J. Bacteriol. 169: 2092-2095.

Ko, J.H., Lee, S.J., Cho, B., and Lee, Y. 2005. Differential promoter usage of infA in response to cold shock in Escherichia coli. FEBS Lett. 580: 539-544.

Marchant, R.J., Al-Fageeh, M.B., Underhill, M.F., Racher, A.J., and Smales, C.M. 2008. Metabolic rates, growth phase, and mRNA levels influence cell-specific antibody production levels from in vitro-cultured mammalian cells at sub-physiological temperatures. Mol. Biotechnol. 39: 69-77.

Mignone, F., Gissi, C., Liuni, G., and Pesole, G. 2002. Untranslated regions of mRNAs. Genome Biol. 3: 0004.1-0004.10. doi: 10.1186/ gb-2002-3-3-reviews0004.

Mitchell, S.A., Spriggs, K.A., Bushell, M., Evans, J.R., Stoneley, M., Le Quesne, J.P., Spriggs, R.V., and Willis, A.E. 2005. Identification of a motif that mediates polypyrimidine tract-binding proteindependent internal ribosome entry. Genes \& Dev. 19: 1556-1571.

Mitta, M., Fang, L., and Inouye, M. 1997. Deletion analysis of $\operatorname{csp} A$ of Escherichia coli: Requirement of the AT-rich UP element for $\operatorname{csp} A$ transcription and the downstream box in the coding region for its cold shock induction. Mol. Microbiol. 26: 321-335.

Murata, Y., Homma, T., Kitagawa, E., Momose, Y., Sato, M.S., Odani, M., Shimizu, H., Hasegawa-Mizusawa, M., Matsumoto, R., Mizukami, S., et al. 2005. Genome-wide expression analysis of yeast response during exposure to $4^{\circ} \mathrm{C}$. Extremophiles 10: 117-128.

Nishiyama, H., Higashitsuji, H., Yokoi, H., Itoh, K., Danno, S. Matsuda, T., and Fujita, J. 1997a. Cloning and characterization of human CIRP (cold-inducible RNA-binding protein) cDNA and chromosomal assignment of the gene. Gene 204: 115-120.

Nishiyama, H., Itoh, K., Kaneko, Y., Kishishita, M., Yoshida, O., and Fujita, J. 1997b. A glycine-rich RNA-binding protein mediating cold-inducible suppression of mammalian cell growth. J. Cell Biol. 137: 899-908.

Nishiyama, H., Danno, S., Kaneko, Y., Itoh, K., Yokoi, H., Fukumoto, M., Okuno, H., Millan, J.L., Matsuda, T., Yoshida, O., et al. 1998a. Decreased expression of cold-inducible RNA-binding protein (CIRP) in male germ cells at elevated temperature. Am. J. Pathol. 152: 289-296.

Nishiyama, H., Xue, J.H., Sato, T., Fukuyama, H., Mizuno, N., Houtani, T., Sugimoto, T., and Fujita, J. 1998b. Diurnal change of the cold-inducible RNA-binding protein (Cirp) expression in mouse brain. Biochem. Biophys. Res. Commun. 245: 534-538.
Phadtare, S. 2004. Recent developments in bacterial cold-shock response. Curr. Issues Mol. Biol. 6: 125-136.

Phadtare, S., Alsina, J., and Inouye, M. 1999. Cold-shock response and cold-shock proteins. Curr. Opin. Microbiol. 2: 175-180.

Roobol, A., Carden, M.J., Newsam, R.J., and Smales, C.M. 2009. Biochemical insights into the mechanisms central to the response of mammalian cells to cold-stress and subsequent rewarming. FEBS J. 276: 286-302.

Sahara, T., Goda, T., and Ohgiya, S. 2002. Comprehensive expression analysis of time-dependent genetic responses in yeast cells to low temperature. J. Biol. Chem. 277: 50015-50021.

Sakurai, T., Itoh, K., Higashitsuji, H., Nonoguchi, K., Liu, Y., Watanabe, H., Nakano, T., Fukumoto, M., Chiba, T., and Fujita, J. 2006. Cirp protects against tumor necrosis factor- $\alpha-$ induced apoptosis via activation of extracellular signal-regulated kinase. Biochim. Biophys. Acta 1763: 290-295.

Smart, F., Aschrafi, A., Atkins, A., Owens, G.C., Pilotte, J., Cunningham, B.A., and Vanderklish, P.W. 2007. Two isoforms of the cold-inducible mRNA-binding protein RBM3 localize to dendrites and promote translation. J. Neurochem. 101: 1367-1379.

Sonna, L.A., Fujita, J., Gaffin, S.L., and Lilly, C.M. 2002. Effects of heat and cold stress on mammalian gene expression. J. Appl. Physiol. 92: $1725-1742$.

Stoneley, M., Paulin, F.E., Le Quesne, J.P., Chappell, S.A., and Willis, A.E. 1998. C-Myc $5^{\prime}$ untranslated region contains an internal ribosome entry segment. Oncogene 16: 423-428.

Subkhankulova, T., Mitchell, S.A., and Willis, A.E. 2001. Internal ribosome entry segment-mediated initiation of c-Myc protein synthesis following genotoxic stress. Biochem. J. 359: 183-192.

Tan, J.S., Mohandas, N., and Conboy, J.G. 2005. High frequency of alternative first exons in erythroid genes suggests a critical role in regulating gene function. Blood 107: 2557-2561.

Ulusu, N.N. and Tezcan, E.F. 2001. Cold shock proteins. Turk. J. Med. Sci. 31: 283-290.

Van Eden, M.E., Byrd, M.P., Sherrill, K.W., and Lloyd, R.E. 2004. Demonstrating internal ribosome entry sites in eukaryotic mRNAs using stringent RNA test procedures. RNA 10: 720-730.

Weber, M.H. and Marahiel, M.A. 2003. Bacterial cold shock responses. Sci. Prog. 86: 9-75.

Wellmann, S., Buhrer, C., Moderegger, E., Zelmer, A., Kirschner, R., Koehne, P., Fujita, J., and Seeger, K. 2004. Oxygen-regulated expression of the RNA-binding proteins RBM3 and CIRP by a HIF-1-independent mechanism. J. Cell Sci. 117: 1785-1794. 
RNA 15: 1164-1176 (2009)

\section{Corrigendum: Cold-inducible RNA binding protein (CIRP) expression is modulated by alternative mRNAs}

\section{MOHAMED B. AL-FAGEEH and C. MARK SMALES}

In the above-noted article, the affiliation for the first author (Mohamed B. Al-Fageeh) was incomplete. The complete affiliation information for authors is listed below:

Mohamed B. Al-Fageeh ${ }^{1,2}$ and C. Mark Smales ${ }^{1}$

${ }^{1}$ Protein Science Group, Department of Biosciences, University of Kent, Canterbury, Kent, CT2 7NJ, United Kingdom

${ }^{2}$ National Centre for Biotechnology, King Abdulaziz City for Science and Technology (KACST), Riyadh 11442, Saudi Arabia The authors apologize for this omission.

doi: $10.1261 /$ rna.063818.117 



A PUBLICATION OF THE RNA SOCIETY

\title{
Cold-inducible RNA binding protein (CIRP) expression is modulated by alternative mRNAs
}

\author{
Mohamed B. Al-Fageeh and C. Mark Smales
}

RNA 2009 15: 1164-1176 originally published online April 27, 2009

Access the most recent version at doi:10.1261/rna.1179109
Related Content
Corrigendum: Cold-inducible RNA binding protein (CIRP) expression is modulated by alternative mRNAs
Mohamed B. Al-Fageeh and C. Mark Smales
RNA December , 2017 23: 1961
References This article cites 42 articles, 12 of which can be accessed free at: http://rnajournal.cshlp.org/content/15/6/1164.full.html\#ref-list-1
Articles cited in:
http://rnajournal.cshlp.org/content/15/6/1164.full.html\#related-urls
License
Email Alerting Receive free email alerts when new articles cite this article - sign up in the box at the Service top right corner of the article or click here.

